\title{
Pengaturan Penerimaan Negara Bukan Pajak Sebagai Wadah Perlindungan Hukum Keuangan Negara
}

\author{
Anindita \\ Fakultas Hukum Universitas Widya Mataram \\ Ndalem Mangkubumen KT III/237 Yogyakarta 55132, Indonesia \\ lekakadekana@gmail.com
}

\begin{abstract}
This study aims to find out how non-tax state revenue regulations apply to the Ministry of Agrarian and Spatial Planning / National Land Agency. This study takes data sources using normative law, which is examined is library material or secondary data that includes primary legal materials, secondary legal materials and tertiary legal materials. This research method will examine the subject matter through the juridical-normative approach stated in several laws and regulations, especially the Peraturan Pemerintah Republik Indonesia Nomor 128 Tahun 2015 Tentang Jenis Dan Tarif Atas Jenis Penerimaan Negara Bukan Pajak Yang Berlaku Pada Kementerian Agraria dan Tata Ruang/Badan Pertanahan Nasional. This study uses one of them with the statutory approach. Because what will be examined is the legal protection of state finance in the non-tax state revenue sector.
\end{abstract}

Keywords: Legal Protection, State Finance, State Revenue Regulation.

\begin{abstract}
Abstrak
Penelitian ini bertujuan untuk mengetahui bagaimana regulasi penerimaan negara bukan pajak yang berlaku pada Kementerian Agraria Dan Tata Ruang/Badan Pertanahan Nasional. Penelitian ini mengambil sumber data menggunakan hukum normatif, yang diteliti adalah bahan pustaka atau data sekunder yang mencakup bahan hukum primer, bahan hukum sekunder dan bahan hukum tersier. Metode penelitian ini akan mengkaji pokok permasalahan melalui pendekatan yuridis-normatif yang tertera dalam beberapa peraturan perundang-undangan terutama Peraturan Pemerintah Republik Indonesia Nomor 128 Tahun 2015 Tentang Jenis Dan Tarif Atas Jenis Penerimaan Negara Bukan Pajak Yang Berlaku Pada Kementerian Agraria dan Tata Ruang/Badan Pertanahan Nasional. Penelitian ini mempergunakan salah satunya dengan pendekatan perundang-undangan. Karena yang akan diteliti adalah perlindungan hukum keuangan negara dalam sektor penerimaan negara bukan pajak.
\end{abstract}

Kata kunci: Keuangan Negara, Pengaturan Penerimaan Negara, Perlindungan Hukum.

\section{A. Pendahuluan}

Pungutan terhadap pajak dan pungutan lain yang bersifat memaksa menurut Undang-Undang kepada masyarakat mempunyai tujuan agar negara memiliki pemasukan yang dapat dikelola oleh negara yang dalam hal ini diwakili oleh Pemerintah, baik pemerintah pusat maupun pemerintah daerah, sehingga negara tersebut dapat membangun dan memakmurkan rakyat. Pemerintah pusat maupun pemerintah daerah mempunyai tugas dan fungsi sebagai untuk melayani masyarakat, pengaturan, melindungi, dan pengelolaan kekayaan negara. Sehingga peran 
pemerintah dalam pelaksanaan dibidang penerimaan dan pengeluaran negara sangat penting, pemerintah dapat mengendalikan pengelolaan keuangan secara terpadu dan harmonis kearah kebijaksanaan anggaran yang berimbang dan dinamis. Tidak hanya berfungsi untuk menciptakan anggaran yang berimbang akan tetapi berimbang dalam arti yang selalu meningkat. Semua penerimaan negara berasal dari sumber-sumber pendapatan yang di tetapkan menurut peraturan perundang-undangan yang berlaku dalam APBN. ${ }^{1}$

Pendapatan negara dibagi dalam dua kelompok besar yaitu penerimaan dalam negeri dan hibah. Hibah adalah sumbangan/pemberian dari pihak lain kepada negara baik perorangan maupun badan usaha dan dapat berasal dari dalam negeri maupun luar negeri. Penerimaan dalam negeri terdiri dari Penerimaan Perpajakan dan Penerimaan Negara Bukan Pajak. Salah satu unsur penerimaan negara adalah Penerimaan Negara Bukan Pajak (PNBP). Tujuan perumusan Undang-Undang Penerimaan Negara Bukan Pajak adalah : (a) Menuju kemandirian bangsa dalam pembiayaan Negara dan pembiayaan pembangunan melalui optimalisasi sumbersumber Penerimaan Negara Bukan Pajak dan ketertiban administrasi pengelolaan Penerimaan Negara Bukan Pajak serta penyetoran Penerimaan Negara Bukan Pajak ke Kas Negara; (b) Lebih memberikan kepastian hukum dan keadilan bagi masyarakat berpartisipasi dalam pembiayaan pembangunan sesuai dengan manfaat yang dinikmatinya dari kegiatan-kegiatan yang menghasilkan Penerimaan Negara Bukan Pajak; (c) Menunjang Kebijaksanaan Pemerintah dalam rangka meningkatkan pertumbuhan ekonomi, pemerataan pembangunan dan hasil-hasilnya serta investasi di seluruh wilayah Indonesia; (d) Menunjang upaya terciptanya aparat pemerintah yang kuat, bersih dan berwibawa, penyederhanaan prosedur dan pemenuhan kewajiban, peningkatan tertib administrasi keuangan dan anggaran negara, serta peningkatan pengawasan. ${ }^{2}$

Pada tahun 2002 Pemerintah menetapkan Peraturan Pemerintah Nomor 46 Tahun 2002 tentang Tarif atas Jenis Penerimaan Negara Bukan Pajak yang Berlaku

\footnotetext{
${ }^{1}$ Meita Amallia, "Analisis Sistem PNBP Untuk Meningkatkan Efektifitas Kinerja Pada KPPN Surabaya I", Jurnal Ilmu \& Riset Akuntansi, Vol. 4 No. 12, 2015, h. 2-3.

2 Ibid. Pengertian pajak itu sendiri adalah iuran rakyat kepada kas negara berdasarkan undangundang dengan tiada pendapat balas jasa secara langsung individual. Vide Tunggul Anshari Setia Negara, 2017, Ilmu Hukum Pajak, Malang: Setara Press, h. 5.
} 
pada Badan Pertanahan Nasional. Kemudian sehubungan dengan adanya jenis penerimaan negara bukan pajak yang baru dan perubahan tarif atas jenis penerimaan negara bukan pajak pada Badan Pertanahan Nasional, penyederhanaan dalam penetapan tarif penerimaan negara bukan pajak, serta dalam upaya mengoptimalkan penerimaan negara bukan pajak guna menunjang pembangunan nasional, Pemerintah kembali menetapkan Peraturan Pemerintah Nomor 13 Tahun 2002 tentang Tarif atas Jenis Penerimaan Negara Bukan Pajak yang Berlaku pada Badan Pertanahan Nasional. Dengan ditetapkannya Peraturan Pemerintah ini diharapkan dapat meningkatkan penerimaan negara bukan pajak pada Badan Pertanahan Nasional untuk dikelola dan dimanfaatkan dalam rangka peningkatan pelayanan kepada masyarakat. $^{3}$

Adapun penerimaan negara bukan pajak yang berlaku pada Kementerian Agraria Dan Tata Ruang/Badan Pertanahan Nasional menimbulkan beberapa pertanyaaan yang perlu dijawab yaitu, Bagaimana pengaturan Penerimaan Negara Bukan Pajak?, Bagaimana pengaturan pengaturan penerimaan negara bukan pajak yang berlaku pada Kementerian Agraria Dan Tata Ruang/Badan Pertanahan Nasional sebagai wadah perlindungan hukum keuangan negara?

\section{B. Telaah Konsep}

Secara konseptual, mengenai pengaturan penerimaan negara bukan pajak peneliti merujuk terhadap Pasal 1, Pasal 2, dan Pasal 3 Peraturan Pemerintah Republik Indonesia Nomor 128 Tahun 2015 Tentang Jenis Dan Tarif Atas Jenis Penerimaan Negara Bukan Pajak Yang Berlaku Pada Kementerian Agraria dan Tata Ruang/Badan Pertanahan Nasional. Dalam Pasal 1 dijelaskan bahwa Penerimaan Negara Bukan Pajak Yang Berlaku Pada Kementerian Agraria dan Tata Ruang/Badan Pertanahan Nasional adalah, sebagai berikut:

1. Pelayanan Survei, Pengukuran, dan Pemetaan;

2. Pelayanan Pemeriksaan Tanah;

3. Pelayanan Konsolidasi Tanah Secara Swadaya;

4. Pelayanan Pertimbangan Teknis Pertanahan;

${ }^{3}$ Peraturan Pemerintah Nomor 13 Tahun 2002 tentang Tarif Atas Jenis Penerimaan Negara Bukan Pajak Yang Berlaku Pada Badan Pertanahan Nasional 
5. Pelayanan Pendaftaran Tanah;

6. Pelayanan Informasi Pertanahan;

7. Pelayanan Lisensi;

8. Pelayanan Pendidikan;

9. Pelayanan Penetapan Tanah Objek Penguasaan Benda-Benda Tetap

Milik perseorangan Warga Negara Belanda (P3MB)/ Peraturan Presidium Kabinet Dwikora Nomor 5/Prk/1965. Pelayanan di Bidang Pertanahan yang Berasal dari Kerja Sama dengan Pihak Lain atau Instansi Pemerintah dan Pemerintah Daerah; dan Pelayanan Pendaftaran Pemberian Hak Bekas Tanah Terlantar. Sedangkan jenis Penerimaan Negara Bukan Pajak yang berasal dari Pelayanan Survei, Pengukuran, dan Pemetaan sebagaimana dimaksud, adalah sebagai berikut;

1. Pelayanan Survei, Pengukuran Batas Kawasan atau Batas Wilayah, dan Pemetaan;

2. Pelayanan Pengukuran dan Pemetaan Bidang Dalam Rangka Penetapan Batas, yang meliputi:

3. Pelayanan Pengukuran dan Pemetaan Batas Ruang Atas Tanah, Ruang Bawah Tanah, atau Ruang Perairan.

Dengan demikian, penulis menyimpulkan bahwa Penerimaan Negara Bukan Pajak Yang Berlaku Pada Kementerian Agraria dan Tata Ruang/Badan Pertanahan Nasional, sebagai bagian dari pendapatan negara yang dalam hal ini menjadi bagian dari pembahasan keuangan negara.

\section{Metode Penelitian}

Adapun metode yang digunakan dalam penelitian ini adalah :

1. Obyek Penelitian

Obyek Penelitian ini adalah Peraturan Pemerintah Republik Indonesia Nomor 128 Tahun 2015 Tentang Jenis Dan Tarif Atas Jenis Penerimaan Negara Bukan Pajak Yang Berlaku Pada Kementerian Agraria dan Tata Ruang/Badan Pertanahan Nasional). 


\section{Sumber Data}

Penelitian ini menggunakan hukum normatif, yang diteliti adalah bahan pustaka atau data sekunder yang mencakup bahan hukum primer, bahan hukum sekunder dan bahan hukum tersier. ${ }^{4}$

a) Bahan primer, yaitu bahan-bahan yang sifatnya mengikat dalam bentuk hukum yang meliputi:

1) UUD 1945

2) Undang Undang tentang Perpajakan

3) Peraturan Pemerintah Republik Indonesia Nomor 128 Tahun 2015 Tentang Jenis Dan Tarif Atas Jenis Penerimaan Negara Bukan Pajak Yang Berlaku Pada Kementerian Agraria dan Tata Ruang/Badan Pertanahan Nasional)

b) Bahan hukum sekunder, yaitu materi-materi politik dan hukum yang menjelaskan data primer baik dari buku-buku, hasil penelitian, jurnal, makalah, artikel dan segala sesuatu yang berkaitan dengan penelitian ini.

c) Bahan hukum tersier, yaitu materi-materi yang memberi petunjuk akan penjelasan data primer dan sekunder, diantaranya:

1) Kamus hukum

2) Ensiklopedi hukum

3) Kamus besar bahasa Indonesia

3. Teknik Pengumpulan Data dan Metode Pendekatan

Metode penelitian ini akan mengkaji pokok permasalahan melalui pendekatan yuridis-normatif. Selain itu penelitian ini juga menggunakan pendekatan studi lapangan sebagai pendukung berdasarkan ruang lingkup dan identifikasi masalah yang ada. Hal ini dimaksudkan agar penelitian ini sejauh mungkin dapat mengetahui pengaturan penerimaan negara bukan pajak pada kementrian Agraria Dan Tata Ruang/Badan Pertanahan Nasional Sebagai Wadah Perlindungan Hukum Keuangan Negara.

4. Analisis Data

Untuk mengkaji pokok permasalahan, penelitian ini mempergunakan metode penelitian hukum normatif dan sekaligus metode penelitian hukum

\footnotetext{
${ }^{4}$ Soerjono Soekanto, 1986, Pengantar Penelitian Hukum, Jakarta: UI Press, h. 10.
} 
empiris. Dengan meneliti bahan pustaka yang ada. Salah satunya dengan pendekatan perundang-undangan. Karena yang akan diteliti adalah berbagai aturan hukum yang menjadi fokus sekaligus tema sentral suatu penelitian. ${ }^{5}$

Akan tetapi penelitian ini akan lebih menitikberatkan pada penelitian hukum normatif. Sedangkan penelitian hukum empiris berfungsi sebagai informasi pendukung saja. Dengan menyesuaikan diri dengan ruang lingkup dan identifikasi masalah yang telah dikemukakan diatas. Pendekatan yang bersifat yuridis-normatif tersebut akan dilakukan dengan mempergunakan bahan hukum primer, bahan hukum sekunder dan bahan hukum tersier. ${ }^{6}$

\section{Pembahasan}

Indonesia adalah salah satu Negara berkembang yang melaksanakan pembangunan. Salah satu pembangunan yang dilaksanakan adalah Pembangunan Nasional. Pembangunan Nasional adalah kegiatan yang berlangsung secara terus menerus dan berkesinambungan yang bertujuan untuk menciptakan tatanan masyarakat yang adil dan makmur, materil dan spritual. Agar tujuan tersebut terwujud maka pemerintah membutuhkan dana yang tidak sedikit yang setiap tahunnya dituangkan dalam Anggaran Pendapatan dan Belanja Negara (APBN). Anggaran Pendapatan dan Belanja Negara (APBN) merupakan salah satu instrumen bagi pemerintah untuk mengendalikan penerimaan dan pengeluaran negara selama satu tahun anggaran, dalam rangkan pencapaian cita-cita pembangunan negara. Pendapatan negara dan hibah adalah salah satu dari struktur APBN yang diperoleh dari : 1) Penerimaan pajak, 2) Penerimaan Negara Bukan Pajak (PNBP) dan 3) Penerimaan Hibah dari dalam Negeri dan luar Negeri. Sedangkan fungsi penerimaan pajak menurut Rismawati Sudirman dan Antong Amiruddin, mempunyai tiga fungsi yaitu: ${ }^{7}$ 1) fungsi pendapatan, 2) fungsi stabilitas, dan 3) fungsi pemerataan.

\footnotetext{
${ }^{5}$ Johny Ibrahim, 2006, Teori dan Metodologi Penelitian Hukum Normatif, Malang: Bayu Media, h. 302.

${ }^{6}$ Soerjono Soekanto, Pengantar Penelitian...., Op.Cit., h. 29.

7 Rismawati Sudirman dan Antong Amiruddin, 2012, Perpajakan Pendekatan Teori dan Praktik, Malang: Empat Dua Media, h. 3.
} 
Penerimaan Negara Bukan Pajak (PNBP) merupakan salah satu unsur penerimaan negara yang masuk di dalam struktur Anggaran Pendapatan dan Belanja Negara (APBN). PNBP timbul karena adanya pelaksanaan tugas dan fungsi pemerintahan dalam pelayanan, pengaturan, perlindungan masyarakat, pengelolaan kekayaan negara termasuk pemanfaatan sumber daya alam. PNBP mempunyai peranan yang penting terhadap tercapainya target APBN yang diharapkan pemerintah. Untuk mencapai target PNBP, diperlukan langkahlangkah strategis oleh pemerintah di bidang pendapatan negara. Sesuai dengan Undang Undang Nomor 20 Tahun 1997 tentang PNBP, PNBP dapat dikelompokkan menjadi : ${ }^{8}$

1. Penerimaan yang berasal dari pengelolaan dana pemerintah;

2. Penerimaan yang berasal dari pemanfaatan sumber daya alam;

3. Penerimaan yang berasal dari kegiatan pelayanan yang dilaksanakan oleh pemerintah;

4. Penerimaan berdasarkan putusan pengadilan dan yang berasal dari pengenaan denda administrasi;

5. Penerimaan yang berasal dari hibah yang menjadi hak pemerintah; dan

6. Penerimaan yang diatur dalam undang-undang tersendiri.

Tarif atas jenis PNBP ditetapkan dengan memperhatikan dampak pengenaan terhadap masyarakat dan kegiatan usahanya, biaya penyelenggaraan kegiatan pemerintahan sehubungan dengan jenis PNBP yang bersangkutan dan aspek keadilan dalam pengenaan beban terhadap masyarakat.

Seluruh PNBP dikelola dalam sistem APBN. Siklus pengelolaan PNBP dimulai dari tahap perencanaan (penetapan target dan pagu penggunaan PNBP), pelaksanaan (penentuan jumlah PNBP terhutang, pemungutan dan penagihan atas jumlah PNBP terhutang, serta pembayaran dan penyetoran atas jumlah PNBP terhutang) dan pertanggungjawaban PNBP. Karena luasnya lingkup pengelolaan PNBP maka tidak sedikit masalah yang timbul dalam pengelolaan PNBP. BPK

${ }^{8}$ Pengelolaan pajak sebagai bagian dari suatu pengelolaan perekonomian negara tentu perlu kita sadari bahwa dengan perkembangan yang begitu pesat, UUD negara modern tidak lagi sebagai dokumen politik namun juga sebagai dokuen ekonomi yang mempengaruhi dinamika perkembangan perekonomian suatu negara. Vide Jimly Asshiddiqie, 2010, Konstitusi Ekonomi, Jakarta: Penerbit Kompas, h. 213. 
dalam hasil pemeriksaan atas pengelolaan PNBP sering menemukan masalah pengelolaan PNBP seperti pungutan PNBP tanpa dasar hukum dan/atau dikelola di luar mekanisme APBN, PNBP terlambat/belum disetor ke kas negara dan PNBP digunakan langsung tanpa disetor ke kas Negara.

Peranan PNBP SDA masih mendominasi khususnya yang berasal dari SDA minyak dan gas bumi serta SDA non migas. Hal ini dapat dilihat dari data Laporan Keuangan Pemerintah Pusat Tahun 2008 s.d. 2012 dan Undang Undang Nomor 15 Tahun 2013 tentang APBN-P Tahun 2013 dimana kontribusi rata-rata SDA migas dan SDA non-migas mencapai 65\% dari total PNBP.

\section{Pengaturan Penerimaan Negara Bukan Pajak yang berlaku pada}

\section{Kementerian Agraria Dan Tata Ruang/Badan Pertanahan Nasional}

Negara sebagai badan publik memiliki fungsi yang waib diembannya sebagaimana yang tercantum dalam UUD 1945 alinea keempat pada pembukaan. Fungsi tersebut adalah 1) melindung segenap bangsa Indonesia dan seluruh tumpah darah Indonesia, 2) untuk memajukan kesejahteraan umum, 3) mencerdaskan kehidupan bangsa, dan 4) ikut melaksanakan ketertiban dunia yang berdasarakan kemerdekaan, perdamaian abadi dan keadilan sosial tidak dapat terlaksana bila tidak ditopang dengan keuangan negara sebagai sumber pembiayaan. ${ }^{9}$

Jenis Penerimaan Negara Bukan Pajak yang berlaku pada Kementerian Agraria dan Tata Ruang/Badan Pertanahan Nasional adalah penerimaan yang berasal dari: ${ }^{10}$

a) Pelayanan Survei, Pengukuran, dan Pemetaan;

b) Pelayanan Pemeriksaan Tanah;

c) Pelayanan Konsolidasi Tanah Secara Swadaya;

d) Pelayanan Pertimbangan Teknis Pertanahan;

e) Pelayanan Pendaftaran Tanah;

f) Pelayanan Informasi Pertanahan;

g) Pelayanan Lisensi;

${ }^{9}$ Muhammad Djafar Saidi, 2013, Hukum Keuanngan Negara, Jakarta: Rejawali Pers, h. 9.

10 Vide Pasal 1 Peraturan Pemerintah Republik Indonesia Nomor 128 Tahun 2015 tentang Jenis Dan Tarif Atas Jenis Penerimaan Negara Bukan Pajak Yang Berlaku Pada Kementerian Agraria dan Tata Ruang/Badan Pertanahan Nasional 
h) Pelayanan Pendidikan;

i) Pelayanan Penetapan Tanah Objek Penguasaan Benda-benda Tetap Milik Perseorangan Warga Negara Belanda (P3MB)/Peraturan Presidium Kabinet Dwikora Nomor 5/Prk/1965;

j) Pelayanan di Bidang Pertanahan yang Berasal dari Kerja Sama dengan Pihak Lain atau Instansi Pemerintah dan Pemerintah Daerah; dan

k) Pelayanan Pendaftaran Pemberian Hak Bekas Tanah Terlantar.

Jenis Penerimaan Negara Bukan Pajak yang berasal dari Pelayanan Survei, Pengukuran, dan Pemetaan sebagaimana dimaksud dalam Pasal 1 huruf a, meliputi: ${ }^{11}$

a) Pelayanan Survei, Pengukuran Batas Kawasan atau Batas Wilayah, dan Pemetaan;

b) Pelayanan Pengukuran dan Pemetaan Bidang Tanah Dalam Rangka Penetapan Batas, yang meliputi:

1) Pelayanan Pengukuran dan Pemetaan Batas Bidang Tanah;

2) Pelayanan Pengukuran dan Pemetaan Batas Bidang Tanah Secara Massal;

3) Pelayanan Pengembalian Batas; dan

4) Pelayanan Legalisasi Gambar Ukur Surveyor Berlisensi.

c) Pelayanan Pengukuran dan Pemetaan Batas Ruang Atas Tanah, Ruang Bawah Tanah, atau Ruang Perairan.

Tarif Pelayanan Survei, Pengukuran Batas Kawasan atau Batas Wilayah, dan Pemetaan sebagaimana dimaksud dalam Pasal 2 huruf a adalah sebagaimana ditetapkan dalam Lampiran Peraturan Pemerintah ini. ${ }^{12}$

Tarif Pelayanan Pengukuran dan Pemetaan Batas Ruang Atas Tanah, Ruang Bawah Tanah, atau Ruang Perairan sebagaimana dimaksud dalam Pasal 2 huruf c adalah sebesar 300\% (tiga ratus persen) dari tarif Pelayanan Pengukuran dan Pemetaan Batas Bidang Tanah sebagaimana dimaksud dalam Pasal 4 ayat (1). ${ }^{13}$

${ }^{11}$ Ibid., Pasal 2

12 Ibid., Pasal 3

${ }^{13}$ Ibid., Pasal 5 
Jenis Penerimaan Negara Bukan Pajak yang berasal dari Pelayanan Pemeriksaan Tanah sebagaimana dimaksud dalam Pasal 1 huruf b, meliputi: ${ }^{14}$

a) Pelayanan Pemeriksaan Tanah oleh Panitia A;

b) Pelayanan Pemeriksaan Tanah oleh Panitia B;

c) Pelayanan Pemeriksaan Tanah oleh Tim Peneliti Tanah; dan

d) Pelayanan Pemeriksaan Tanah oleh Petugas Konstatasi.

Tarif Pelayanan Pemeriksaan Tanah oleh Petugas Konstatasi sebagaimana dimaksud dalam Pasal 6 huruf d, adalah sebesar 50\% (lima puluh persen) dari Tarif Pelayanan Pemeriksaan Tanah oleh Panitia A sebagaimana dimaksud dalam Pasal 7 ayat (1). ${ }^{15}$

Jenis Penerimaan Negara Bukan Pajak yang berasal dari Pelayanan Konsolidasi Tanah Secara Swadaya sebagaimana dimaksud dalam Pasal 1 huruf c, meliputi: ${ }^{16}$

a) Pelayanan Konsolidasi Tanah Secara Swadaya Pertanian;

b) Pelayanan Konsolidasi Tanah Secara Swadaya Non Pertanian.

Jenis Penerimaan Negara Bukan Pajak yang berasal dari Pelayanan Pertimbangan Teknis Pertanahan sebagaimana dimaksud dalam Pasal 1 huruf d, meliputi: ${ }^{17}$

a) Pelayanan Pertimbangan Teknis Pertanahan dalam rangka Izin Lokasi;

b) Pelayanan Pertimbangan Teknis Pertanahan dalam rangka Penetapan Lokasi; dan

c) Pelayanan Pertimbangan Teknis Pertanahan dalam rangka Izin Perubahan Penggunaan Tanah.

Jenis Penerimaan Negara Bukan Pajak yang berasal dari Pelayanan Pendaftaran Tanah sebagaimana dimaksud dalam Pasal 1 huruf e meliputi: ${ }^{18}$

a) Pelayanan Pendaftaran Tanah Untuk Pertama Kali; dan

b) Pelayanan Pemeliharaan Data Pendaftaran Tanah.

\footnotetext{
${ }^{14}$ Ibid., Pasal 6

15 Ibid., Pasal 10

${ }^{16}$ Ibid., Pasal 11

17 Ibid., Pasal 13

${ }^{18}$ Ibid., Pasal 15
} 
Tarif Pelayanan Penetapan Tanah Objek Penguasaan Benda-benda Tetap Milik Perseorangan Warga Negara Belanda (P3MB)/Peraturan Presidium Kabinet Dwikora Nomor 5/Prk/1965 sebagaimana dimaksud dalam Pasal 1 huruf i adalah sebesar $25 \%$ (dua puluh lima persen) dari nilai tanah. ${ }^{19}$

Tarif Pelayanan di Bidang Pertanahan yang Berasal Dari Kerja Sama dengan Pihak Lain atau Instansi Pemerintah dan Pemerintah Daerah sebagaimana dimaksud dalam Pasal 1 huruf $\mathbf{j}$ yang ditujukan untuk masyarakat adalah sebesar biaya Pensertifikatan Tanah PRONA tahun berjalan. Kerja sama yang dilakukan dengan Instansi Pemerintah dan Pemerintah Daerah sebagaimana dimaksud pada ayat (1) menggunakan anggaran yang berasal dari APBN/APBD. ${ }^{20}$

Tarif Pendaftaran Pemberian Hak Bekas Tanah Terlantar sebagaimana dimaksud dalam Pasal 1 huruf $\mathrm{k}$ untuk:

a) Perorangan melalui reforma agraria adalah sebesar Rp 0,00 (nol rupiah)

b) Instansi Pemerintah untuk melaksanakan tugas dan fungsinya dan tidak bersifat profit adalah sebesar Rp 0,00 (nol rupiah);

c) Yayasan yang bergerak di bidang pendidikan dan kesehatan adalah sebesar $25 \%$ (dua puluh lima persen) dari nilai tanah;

d) Badan Usaha Milik Negara/Badan Hukum Milik Negara/Badan Usaha Milik Daerah adalah sebesar 75\% (tujuh puluh lima persen) dari nilai tanah;

e) Badan Hukum Swasta adalah sebesar 100\% (seratus persen) dari nilai tanah.

Terhadap pihak tertentu dapat dikenakan tarif sebesar Rp 0,00 (nol rupiah) dari tarif atas jenis Penerimaan Negara Bukan Pajak berupa :

a) Pelayanan Pengukuran dan Pemetaan Batas Bidang Tanah sebagaimana dimaksud dalam Pasal 2 huruf b angka 1;

b) Pelayanan Pemeriksaan Tanah oleh Panitia A sebagaimana dimaksud dalam Pasal 6 huruf a atau Pelayanan Pemeriksaan Tanah oleh Petugas Konstatasi sebagaimana dimaksud dalam Pasal 6 huruf d; dan/atau

c) Pelayanan Pendaftaran Tanah berupa Pelayanan Pendaftaran Tanah untuk Pertama Kali sebagaimana dimaksud dalam Pasal 15 huruf a.

${ }_{19}$ Ibid., Pasal 18

${ }^{20}$ Ibid., Pasal 19 
Pihak tertentu sebagaimana dimaksud pada ayat (1) terdiri atas :

a) Masyarakat tidak mampu;

b) Masyarakat yang termasuk dalam Program Pemerintah Bidang Perumahan Sederhana;

c) Badan hukum yang bergerak di bidang keagamaan dan sosial yang penggunaan tanahnya untuk peribadatan, pesantren, panti asuhan, panti jompo, cagar budaya, situs/tempat ziarah;

d) Veteran, Pensiunan PNS, Purnawirawan TNI, Purnawirawan POLRI dan Suami/Istri/Janda/DudaVeteran/Pensiunan PNS/Purnawirawan TNI/Purnawirawan POLRI;

e) Instansi Pemerintah dan Pemerintah Daerah, untuk melaksanakan tugas dan fungsinya dan tidak bersifat profit;

f) Wakif; atau

g) Masyarakat Hukum Adat.

Terhadap masyarakat sebagaimana dimaksud pada ayat (2) huruf b yang akan menjaminkan tanah dan bangunan atau rumah susun yang berasal dari Program Pemerintah Bidang Perumahan Sederhana, dapat dikenakan tarif sebesar Rp 0,00 (nol rupiah) dari tarif atas jenis Penerimaan Negara Bukan Pajak berupa Pelayanan Pendaftaran Hak Tanggungan/Pendaftaran Akta Pemberian Hak Tanggungan (APHT) dengan Nilai Hak Tanggungan sampai dengan Rp 250.000.000,- (dua ratus lima puluh juta rupiah) dari Pelayanan Pemeliharaan Data Pendaftaran Tanah.

Tarif Pelayanan Pendaftaran Tanah dari Pelayanan Pemeliharaan Data Pendaftaran Tanah berupa Pelayanan Pendaftaran Penggantian Nazhir ditetapkan sebesar Rp 0,00 (nol rupiah).

Terhadap pihak tertentu dapat dikenakan tarif sebesar 50\% (lima puluh persen) dari tarif atas jenis Penerimaan Negara Bukan Pajak berupa:

a) Tarif Pelayanan Pengukuran dan Pemetaan Batas Bidang Tanah sebagaimana dimaksud dalam Pasal 2 huruf b angka 1;

b) Pelayanan Pemeriksaan Tanah oleh Panitia A sebagaimana dimaksud dalam Pasal 6 huruf a atau Pelayanan Pemeriksaan Tanah oleh Petugas Konstatasi sebagaimana dimaksud dalam Pasal 6 huruf d; dan/atau 
c) Pelayanan Pendaftaran Tanah berupa Pelayanan Pendaftaran Tanah untuk Pertama Kali sebagaimana dimaksud dalam Pasal 15 huruf a.

Pihak tertentu sebagaimana dimaksud pada ayat (1) terdiri atas :

a) PNS, Prajurit TNI, Anggota POLRI dan Suami / Istri PNS / TNI / POLRI;

b) BUMN / BUMD;

c) Badan yang mendapat penugasan khusus dari Pemerintah; dan

d) Badan hukum swasta selaku pengelola maupun pengguna Kawasan Industri atau Kawasan Ekonomi Khusus.

\section{Perlindungan Hukum Keuangan Negara dalam Sektor PNBP}

Menurut Arifin P. Soeria Atmadja PNBP dikategorikan dalam UUD Pasa 1 23A dikategorikan sebagai pungutan lain yang bersifat memaksa. Meski Undang Undang Nomor 20 Tahun 1997 tentang Penerimaan Negara Bukan Pajak melaksanakan ketentuan UUD, namun ia tidak dapat digolongkan kedalam undang-undang organik, karena lahirnya undang-undang tentang PNBP lebih dahulu daripada Pasal 23A UUD 1945 (perubahan ketiga). ${ }^{21}$

Ruang lingkup keuangan negara diatur dalam Pasal 2 Undang Undang Keuangan Negara tidak lagi bersifat interpretatif eksistensi, akan tetapi justru merupakan ketentuan yang bersifat ekstensi, yang dalam tataran rasional yuridis justru menjadi tidak logis dan mengandung paradoks didalamnya. Hal itu disebabkan adanya tidak adanya batas antara keuangan negara (publik), baik yang diatur oleh negara maupun daerah, serta hukum keuangan privat. $^{22}$ Pengertian keuangan negara itu sendiri menurut Van der Kempt, adalah semua hak yang dapat dinilai dengan uang, demikian pula segala sesuatu (baik berupa uang ataupun barang) yang dapat dijadikan milik negara berhubungan dengan hak-hak tersebut. ${ }^{23}$

PNBP mempunyai fungsi sebagai perlindungan keuangan negara. Secara spesifik dapat diperinci menjadi dua jenis:

21 Arifin P Soeria Atmadja, 2013, Kenangan Publik dalam Perspektif Hukum: Teori, Praktik, dan Kritik, Jakarta: Rajawali Press, h. 391. Perumusan keuangan negara menggunakan beberapa pendekatan yaitu: 1) pendekatan dari sisi objek, 2) pendekatan dari sisi subjek, 3) pendekatan dari sisi proses, dan 4) pendekatan dari sisi tujuan. Vide Adrian Sutedi, 2012, Hukum Keuangan Negara, Jakarta: Penerbit Sinar Grafika, h. 11.

22 Rahayu Hartini, 2017, BUMN Persero: Konsep Kenangan Negara dan Hukum Kepailitan di Indonesia, Malang: Setara Press, h. 87-88.

${ }^{23}$ W. Riawan Thandra, 2014, Hukum Kenangan Negara, Jakarta: Grasindo, h. 2. 
a) Fungsi Budgeter, dimaksudkan bahwa PNBP sebagai fungsi pembiayaan maka harus diupayakan uang memasukkan uang yang sebesar-besarnya kedalam kas negara untuk menunjang tugas pemerintahan.

b) Fungsi Reguler (pengaturan), PNBP mampu dipergunakan sebagai sarana untuk mengatur kebijakan pemerintah dalam berbagai aspek dalam rangka menggerakkan roda pembangunan potensial.

Penerimaan Negara Bukan Pajak (PNBP) merupakan penerimaan negara yang diperoleh karena pemberian pelayanan jasa/penjualan barang milik negara untuk departemen/lembaga kepada masyarakat. Penerimaan ini dapat berasal dari pungutan dalam bentuk iuran, retribusi, sumbangan atau pungutan yang dikenakan atas pemberian pelayanan/jasa dari negara yang dilakukan oleh departemen/lembaga, penjualan barang milik negara baik yang dilakukan secara lelang umum/terbatas maupun penjualan di bawah tangan, dan penyewaan/peminjaman/pengontrakan barang-barang atau fasilitas milik negara.

Selain berfungsi sebagai salah satu penerimaan, PNBP dapat pula berfungsi sebagai alat pengaturan, seperti dalam kebijaksanaan penentuan tarif dan penyesuaian-penyesuaian berdasarkan Peraturan Menteri Keuangan Nomor 99/PMK.06/2006. PNBP juga berfungsi sebagai unit swadana atas beberapa satuan kerja tertentu dari instansi pemerintahan yang akan dapat melakukan dan mendorong peningkatan mutu pelayanan, memperlancar tugas pelayanan yang diberikan. PNBP sebagai wujud penerimaan juga mampu memberikan rasa kebersamaan dalam mengelola dan membiayai pengeluaran dari berbagai unit/departemen/lembaga yang dalam proses mencapai tujuan harus berjalan bersama dan saling mendukung satu sama lainnya.

\section{E. Penutup}

Penerimaan Negara Bukan Pajak (PNBP) merupakan salah satu unsur penerimaan negara yang masuk di dalam struktur Anggaran Pendapatan dan Belanja Negara (APBN). PNBP timbul karena adanya pelaksanaan tugas dan fungsi pemerintahan dalam pelayanan, pengaturan, perlindungan masyarakat, pengelolaan kekayaan negara termasuk pemanfaatan sumber daya alam. PNBP 
mempunyai peranan yang penting terhadap tercapainya target APBN yang diharapkan pemerintah.

Jenis Penerimaan Negara Bukan Pajak yang berlaku pada Kementerian Agraria dan Tata Ruang/Badan Pertanahan Nasional adalah penerimaan yang berasal dari: Pelayanan Survei, Pengukuran, dan Pemetaan; Pelayanan Pemeriksaan Tanah; Pelayanan Konsolidasi Tanah Secara Swadaya; Pelayanan Pertimbangan Teknis Pertanahan; Pelayanan Pendaftaran Tanah; Pelayanan Informasi Pertanahan; Pelayanan Lisensi; Pelayanan Pendidikan; Pelayanan Penetapan Tanah Objek Penguasaan Benda-benda Tetap Milik Perseorangan Warga Negara Belanda (P3MB)/Peraturan Presidium Kabinet Dwikora Nomor 5/Prk/1965; Pelayanan di Bidang Pertanahan yang Berasal dari Kerja Sama dengan Pihak Lain atau Instansi Pemerintah dan Pemerintah Daerah; dan Pelayanan Pendaftaran Pemberian Hak Bekas Tanah Terlantar.

Jenis Penerimaan Negara Bukan Pajak yang berasal dari Pelayanan Survei, Pengukuran, dan Pemetaan sebagaimana meliputi : Pelayanan Survei, Pengukuran Batas Kawasan atau Batas Wilayah, dan Pemetaan;Pelayanan Pengukuran dan Pemetaan Bidang Tanah Dalam Rangka Penetapan Batas, yang meliputi; Pelayanan Pengukuran dan Pemetaan Batas Bidang Tanah; Pelayanan Pengukuran dan Pemetaan Batas Bidang Tanah Secara Massal; Pelayanan Pengembalian Batas; dan Pelayanan Legalisasi Gambar Ukur Surveyor Berlisensi. Pelayanan Pengukuran dan Pemetaan Batas Ruang Atas Tanah, Ruang Bawah Tanah, atau Ruang Perairan.

PNBP mempunyai fungsi sebagai perlindungan keuangan negara. Secara spesifik dapat diperinci menjadi dua jenis: Fungsi Budgeter, dimaksudkan bahwa PNBP sebagai fungsi pembiayaan maka harus diupayakan uang memasukkan uang yang sebesar-besarnya ke dalam kas negara untuk menunjang tugas pemerintahan. Fungsi Reguler (pengaturan), PNBP mampu dipergunakan sebagai sarana untuk mengatur kebijakan pemerintah dalam berbagai aspek dalam rangka menggerakkan roda pembangunan potensial. 


\section{DAFTAR PUSTAKA}

\section{Buku}

Amallia, Meita, "Analisis Sistem PNBP Untuk Meningkatkan Efektifitas Kinerja Pada KPPN Surabaya I", Jurnal Ilmu \& Riset Akuntansi, Vol. 4 No. 12, 2015.

Asshiddiqie, Jimly, 2010, Konstitusi Ekonomi, Jakarta: Penerbit Kompas.

Atmadja, Arifin P Soeria, 2013, Kenangan Publik dalam Perspektif Hukum: Teori, Praktik, dan Kritik, Jakarta: Rajawali Press.

Hartini, Rahayu, 2017, BUMN Persero: Konsep Keuangan Negara dan Hukum Kepailitan di Indonesia, Malang: Setara Press.

Ibrahim, Johny, 2006, Teori dan Metodologi Penelitian Hukum Normatif, Malang: Bayu Media.

Negara, Tunggul Anshari Setia, 2017, Imu Hukum Pajak, Malang: Setara Press.

Saidi, Muhammad Djafar, 2013, Hukum Keuanngan Negara, Jakarta: Rejawali Pers.

Soekanto, Soerjono, 1986, Pengantar Penelitian Hukum, Jakarta: UI Press.

Sudirman, Rismawati dan Antong Amiruddin, 2012, Perpajakan Pendekatan Teori dan Praktik, Malang: Empat Dua Media.

Sutedi, Adrian, 2012, Hukum Keuangan Negara, Jakarta: Penerbit Sinar Grafika.

Thandra, W. Riawan, 2014, Hukum Keuangan Negara, Jakarta: Grasindo.

\section{Peraturan Perundang-undangan}

Undang Undang Dasar 1945.

Undang-Undang Nomor 17 Tahun 2003 tentang Keuangan Negara.

Undang-Undang Republik Indonesia Nomor 2 Tahun 2000.

Peraturan Pemerintah Republik Indonesia Nomor 128 Tahun 2015 Tentang Jenis Dan Tarif Atas Jenis Penerimaan Negara Bukan Pajak Yang Berlaku Pada Kementerian Agraria dan Tata Ruang/Badan Pertanahan Nasional.

Peraturan Pemerintah Nomor 13 Tahun 2002 tentang Tarif atas Jenis Penerimaan Negara Bukan Pajak yang Berlaku pada Badan Pertanahan Nasional.

Peraturan Pemerintah Republik Indonesia Nomor 22 Tahun 1997. 
Peraturan Presiden Nomor 63 Tahun 2013.

Peraturan Presiden Nomor 10 Tahun 2006 tentang Badan Pertanahan Nasional.

Peraturan Menteri Keuangan Nomor 99/PMK.06/2006. 